\title{
Sosiaalisen median kommenttien analyysi multimodaalisesta näkökulmasta digitaalisen journalismin ja poliittisen viestinnän tutkimuksessa
}

\author{
Margareta Salonen \\ Jyväskylän yliopisto \\ margareta.salonen@jyu.fi \\ https://orcid.org/0000-0001-9635-2251 \\ Elisa Kannasto \\ Vaasan yliopisto, Seinäjoen ammattikorkeakoulu \\ elisa.kannasto@seamk.fi \\ https://orcid.org/0000-0003-1758-982X
}

\author{
Laura Paatelainen \\ Tampereen yliopisto \\ laura.paatelainen@tuni.fi \\ https://orcid.org/0000-0003-2168-9161
}

The significance of societal discussion and participation on social media has not been unnoticed by researchers who are continuously looking for ways to extract and analyze social media data across research fields. Social media platforms afford their users functions that organize communication in these platforms and affect how discussions form and what they look like. In these discussions, multimodality unravels the semiotic modes that are communication resources through which meanings are socially and culturally created and expressed. This systematic literature review was conducted to better understand how social media comments have been researched from the perspective of multimodality in the context of digital journalism and political communication. More precisely, this review focused on studies that had researched Twitter, Facebook, and/or Instagram comments. The studies under review were not prominent in multimodality and text as an individual mode was the most common one. Twitter dominated in the researchers' choices of studied platforms. In addition, the modes were more thoroughly explained in research focused on Twitter even though the idea of comments was more ambiguous within the platform.

Asiasanat: affordanssi, digitaalinen journalismi, kommentit, multimodaalisuus, poliittinen viestintä, sosiaalinen media 


\section{Johdanto}

Sosiaalisesta mediasta on tullut yhteiskunnallisen keskustelun vakiintunut alusta, jossa keskustelevat niin kansalaiset, valtaapitävät kuin mediatoimijatkin (ks. esim. Bruns 2018). Esimerkiksi sanomalehtien ja poliittisten puolueiden sosiaalisen median tileillä käydään keskustelua, ilmaistaan mielipiteitä ja ollaan vuorovaikutuksessa toisten kanssa. Sosiaalisen median palveluiden merkitys on kasvanut myös demokratian turvaamisessa, sillä ihmiset ja yhteiskunnalliset keskustelut ovat siirtyneet viime vuosina enenevissä määrin digitaalisiin sosiaalisiin verkostoihin (Suominen, Saarikoski \& Vaahensalo 2019). Yhteiskunnassa käytävien keskustelujen ja kommenttien tutkiminen on tärkeää, sillä verkon mukaantulon myötä esimerkiksi journalismi nähdään entistä enemmän vuorovaikutuksellisena suhteena journalistien ja yleisöjen välillä (Marchionni 2013, 131). Myös poliittisella kentällä äänestäjät ja poliittiset toimijat toimivat verkossa ja sosiaalisen median palveluissa, joiden julkisessa tilassa rakennetaan ja mahdollistetaan demokratiaa palvelujen käyttäjien välisissä suhteissa (Kim \& Chen 2016; Suominen, Saarikoski \& Vaahensalo 2019).

Yhteiskunnallisen keskustelun lisääntyessä myös tarve tutkia ja ymmärtää sosiaalisen median kommentointia on kasvanut. Sosiaalisen median aineistoja tutkittaessa kohdataan kuitenkin väistämättä kysymys: mistä tutkimuksen fokuksessa oleva aineisto koostuu ja millä menetelmällä sitä olisi järkevä lähestyä? Digitaalisten analysointimenetelmien valinnat vaikuttavat siihen, minkälaista tietoa digitaalisista ympäristöistämme saadaan. Lisäksi aineistoihin ja niiden analyysiin liittyy rajanvetoja, jotka jokaisen tutkijan on omassa tutkimuksessaan tehtävä. Eettiset ja teknologiset näkökulmat nousevat merkittäväksi osaksi muun muassa aineistojen keräämistä. Alustapalvelut määrittävät rajapintojensa ja datansa avoimuutta sekä käyttömahdollisuuksia, ja aineistojen käsittelyssä on huomioitava tutkimusetiikka muun muassa kommentoijien anonymiteetin näkökulmasta; mitä aineistoja voidaan eettisesti kerätä ja julkaista (Markham \& Buchanan 2017, 201-202). Tutkimuskenttänä sosiaalinen media tuo siis omat haasteensa, mutta koska iso osa yhteiskunnallista keskustelua käydään sosiaalisen median alustoilla, tutkijoilla on jo tästä näkökulmasta eettinen velvoite tutkia yhteiskunnan peilinä näyttäytyviä alustoja.

Näin ollen tässä katsauksessa käsitellään digitaalisten analysointimenetelmien käyttöä, tarkalleen ottaen sitä, minkälaisia aineistovalintoja tutkijat ovat sosiaalisen median kommentteja koskevissa tutkimuksissaan tehneet. Valitsimme tarkastelun kohteeksi sosiaalisen median kommentit, sillä jokainen yksittäinenkin kommentti rakentaa yhteiskunnassamme käytävää 
julkista keskustelua. Journalismi puolestaan tarjoaa tilaa tälle julkiselle keskustelulle, ja uutismedioilla on suuri vastuu yleisökommenttien kuratoinnissa (Chen \& Pain 2017). Sosiaalisen median kommentoinnista on tullut myös merkittävä osa poliittista viestintää ja siten tärkeää sen tutkimuskentällä (Boulianne 2015; Kahne \& Bowyer 2018). Näiden seikkojen vuoksi on tarpeellista kiinnittää huomiota siihen, mitä sosiaalisen median kommenttien tutkimus tarkemmin ottaen tarkoittaa ja edellyttää. Katsauksen konteksteiksi valikoituivat digitaalisen journalismin ja poliittisen viestinnän tutkimuskentät, sillä molemmissa tarkastellaan sitä, mikä merkitys yhteiskunnallisella keskustelulla ja yleisöjen verkkotoiminnalla on nyky-yhteiskunnallemme (ks. esim. Steensen ym. 2019; McNair 2003, 4). Katsaukseen sisällytetyt alustat ovat Facebook, Twitter ja Instagram, sillä ne ovat keskeiset sosiaalisen median alustat uutiskulutuksessa (Newman ym. 2020) ja usein eniten käytetyt poliittisessa viestinnässä (Bossetta 2018).

Verkossa kohtaamamme semioottiset eli kielelliset merkit (Tieteen termipankki 2021) muovaavat ajatuksiamme ja tapaamme olla vuorovaikutuksessa toistemme kanssa. Alustoituvaa yhteiskuntaa ja sen viestintää voidaankin tarkastella monella tapaa, mutta tähän sosiaalisen median tutkimuksen kommentteja käsittelevään katsaukseen valitsimme multimodaalisen näkökulman. Sosiaalisen median viestintä nähdään erilaisista semioottisista merkeistä koostuvana multimodaalisena ympäristönä; viestintä tapahtuu kirjoitettujen ja puhuttujen kommenttien kautta tekstin, kuvan ja videon muodossa sekä spesifeille että laajemmillekin joukoille (Djonov \& Van Leeuwen 2018, 641). Sosiaalisen median julkaisut, joiden osaksi myös kommentit muodostuvat, koostuvat siis erilaisista kielellisten merkkien, kuten tekstien, kuvien ja hymiöiden yhdistelmistä. Näitä yksittäisiä merkkejä kutsutaan moodeiksi ja niistä muodostuvat yhdistelmät ovat puolestaan multimodaaleja (Kress 2010). Myös sosiaalisen median kommentit nähdään multimodaalisina elementteinä ja merkittävänä osana nykyistä semioottista kenttää: Djonov ja Van Leeuwenin (2018, 641) mukaan sosiaalisen median kommentit muokkaavat sitä, miten ihmiset viestivät ja ovat yhteyksissä toisiinsa sekä kuluttavat tietoa. Lisäksi he näkevät, että näin ollen sosiaalinen media muuttaa muun muassa politiikkaa, demokratiaa ja uutisointia.

Katsauksemme keskiössä on tämä multimodaalisuuden näkökulma sosiaalisen median kommenttien tutkimuksessa. Multimodaalisuuden näkökulmaa on tutkittu digitaalisen journalismin (ks. esim. Hiippala 2017) ja poliittisen viestinnän (ks. esim. Debus, Stuckenschmidt \& Wessler 2015; Pettersson \& Sakki 2020) tutkimuskentillä. Sosiaalisen median kommentointia ja keskusteluja on puolestaan suomalaisessa tutkimuksessa tutkittu eri näkökulmista: muun muassa normien (Salonen ym. in review), emotio- 
naalisuuden ja affektiivisuuden (Laaksonen \& Pöyry 2018; Rantasila 2018), kriisitilanteiden tiedontarpeen (Haasio ym. 2018), henkilöbrändien rakentumisen (Kannasto 2020) ja intertekstuaalisuuden näkökulmasta (Suominen, Saarikoski \& Vaahensalo 2019). Esimerkiksi näitä aiempia tutkimuksia tarkastellessa nousee esiin se, miten tutkijan valinnat aineiston ja menetelmän suhteen vaikuttavat tutkimusprosessiin ja sen lopputulokseen. Erityisen mielenkiintoiseksi nämä valinnat nousevat, kun havainnoidaan tutkimuksia moodien ja multimodaalisuuden valossa; tarkastelemme tässä katsauksessa mukana olevia tutkimuksia sellaisesta näkökulmasta, jota tutkimuksen tekijät eivät välttämättä ole juurikaan ottaneet huomioon, kuten tuloksemme myöhemmin osoittavat. Tässä katsauksessa mukana olevia tutkimuksia ei ole alun perin tutkittu multimodaalisesta näkökulmasta, vaan me tarkastelemme katsauksen tutkimuksia multimodaalisessa valossa.

Multimodaalisesta näkökulmasta tehtävälle tutkimukselle on tarve, sillä yksittäisten moodien toiminnasta tiedetään huomattavasti enemmän kuin siitä, miten moodien vuorovaikutus ja järjestäytyminen toimii teksteissä ja diskurssissa (Stöckl 2004, 10). Lisäksi kommenttien tutkimuksen haasteeksi muodostuu usein se, miten eri moodit huomioidaan kun valitaan tutkimusmenetelmää ja kerätään aineistoa, etenkin jos digitaalista aineiston keräämistä rajoittaa käytetty ohjelma. Joillakin ohjelmilla, kuten NodeXL:llä, ei voi suoraan kerätä kuvia tai videoita ja osan käyttöä rajoittaa joidenkin aineistokeräys- ja analyysialustojen, kuten Crowdtanglen, luvanvaraisuus. Lisäksi analyysiohjelmistot ja eri alustat eivät välttämättä tarjoa validia aineistoa. Harjun ja Huhtamäen (2021) mukaan Pink ym. (2018) toteamus siitä, että aineisto on monella tapaa rikki pätee esimerkiksi Twitteriin, jossa aineisto reflektoi ainoastaan keräysajankohtaa. He tuovat myös esiin, että valittu keräystapa ja sen asettamat rajoitukset vaikuttavat aineistoon. Analyysivalintoja voi puolestaan ohjata se, että toiset moodit kuten aihetunnisteet eli hashtagit voi olla helpompi tunnistaa ja analysoida isosta aineistosta kuin esimerkiksi tekstin sävy tai viestien varsinainen sisältö tekstimassassa. Esimerkiksi Twitteriä käsitteleviä verkostoanalyysejä on julkaistu runsaasti, sillä digitaaliset menetelmät verkostojen keräämiseen, analysointiin ja visualisointiin ovat kehittyneet nopeasti ja niitä on helposti saatavilla. 


\section{Sosiaalisen median toiminnot, multimodaalisuus ja affordanssit}

Jokaisella sosiaalisen median alustalla on hieman omanlaisensa toimintalogiikka ja toisistaan eriäviä toimintoja, joilla viestintää voidaan organisoida. Alustoista suosituimmat ovat tosin alkaneet muistuttaa toinen toistaan. Esimerkiksi Snapchatista Instagramiin rantautunut tarina-ominaisuus (24 tuntia kestävä video tai kuva) päätyi myös Twitterin valikoimiin hetket-toiminnon nimellä, vaikkakin Twitter poisti tämän toiminnon vuonna 2021. Oheisessa taulukossa (ks. Taulukko 1.) näkyy tässä katsauksessa mukana olevien alustojen, Facebookin, Twitterin ja Instagramin, keskeisiä toimintoja. Kuten taulukosta näkyy, puolet keskeisistä toiminnoista ovat yhteneviä kaikilla kolmella alustalla. Lisäksi alustoilla on käytössä tekstistä muodostuva ja toiselle sivulle ohjaava hyperlinkki-toiminto, joka ei ole yksinomaan sosiaalisen median alustojen toiminto, vaan laajemminkin osa verkon käytön logiikkaa.

Taulukko 1. Facebookin, Twitterin ja Instagramin toiminnot.

\begin{tabular}{|l|l|l|l|}
\hline Facebook & Twitter & Instagram & Toiminnon kuvaus \\
\hline $\begin{array}{l}\text { Julkaisu } \\
\text { Post) }\end{array}$ & $\begin{array}{l}\text { Tviitti } \\
\text { (Tweet) }\end{array}$ & $\begin{array}{l}\text { Julkaisu } \\
\text { (Post) }\end{array}$ & $\begin{array}{l}\text { Viesti, joka voi olla tekstin, videon, kuvan, } \\
\text { linkin tai muun alustakohtaisen toiminnon } \\
\text { muodossa. Instagramissa viesti automaatti- } \\
\text { sesti kuva- tai videopohjaisena ja Twitterissä } \\
\text { rajattuna merkkimääränä (max. 280). }\end{array}$ \\
\hline $\begin{array}{l}\text { Reaktiot } \\
\text { Reactions) }\end{array}$ & $\begin{array}{l}\text { Tykkäys } \\
\text { (Like) }\end{array}$ & $\begin{array}{l}\text { Tykkäys } \\
\text { (Like) }\end{array}$ & $\begin{array}{l}\text { Viestin tai kommentin sisältöön reagoiminen. } \\
\text { Facebookissa useampia reagointitoimintoja: } \\
\text { tykkää, ihastu, läheisyys, haha, vau, surullinen } \\
\text { tai vihainen. }\end{array}$ \\
\hline $\begin{array}{l}\text { Keskustelut } \\
\text { (Messenger) }\end{array}$ & $\begin{array}{l}\text { Yksityisviesti } \\
\text { (Direct } \\
\text { message) }\end{array}$ & $\begin{array}{l}\text { Keskustelut } \\
\text { (Messenger) }\end{array}$ & $\begin{array}{l}\text { Yksityisviestien jakamistoiminto, jolla voi } \\
\text { laittaa viestiä yksityisesti yhdelle tai } \\
\text { useammalle palvelun käyttäjälle. } \\
\text { Viesti voi olla tekstin, videon, kuvan, linkin tai } \\
\text { muun alustakohtaisen toiminnon muodossa. }\end{array}$ \\
\hline $\begin{array}{l}\text { Jako } \\
\text { (Share) }\end{array}$ & $\begin{array}{l}\text { Uudelleen- } \\
\text { tviittaus } \\
\text { (Re-tweet) }\end{array}$ & $\begin{array}{l}\text { Jako / } \\
\text { Lennokki } \\
\text { (Share / } \\
\text { Paper } \\
\text { airplane) }\end{array}$ & $\begin{array}{l}\text { Jako-toiminnolla on alustakohtaisia eroja. } \\
\text { Twitterissä uudelleentviittaus tarkoittaa } \\
\text { viestin uudelleen jakamista omalle seuraa- } \\
\text { jajoukolle. Facebookissa julkaisun voi jakaa } \\
\text { yksityisesti toiselle käyttäjälle keskustelu- } \\
\text { toiminnon kautta tai julkisemmin } \\
\text { rajaamalleen yleisölle omassa profiilissaan. } \\
\text { Instagramissa jakaminen tarkoittaa julkaisun } \\
\text { jakamista yksityisviestinä yhdelle tai } \\
\text { useammalle tai lisäämällä julkaisun tarina- } \\
\text { ominaisuuden kautta omaksi hetkelliseksi } \\
\text { julkaisuksi. }\end{array}$ \\
\hline
\end{tabular}




\begin{tabular}{|c|c|c|c|}
\hline $\begin{array}{l}\text { Maininta } \\
\text { (Mentions } \\
\text { @) }\end{array}$ & $\begin{array}{l}\text { Maininta } \\
\text { (Mentions } \\
\text { @) }\end{array}$ & $\begin{array}{l}\text { Maininta } \\
\text { (Mentions } \\
@ \text { @) }\end{array}$ & $\begin{array}{l}\text { Tiettyyn tiliin/käyttäjään kohdistettu } \\
\text { viestintä, jolla esimerkiksi kutsutaan muita } \\
\text { käyttäjiä vuorovaikutukseen. Alusta luo } \\
\text { hyperlinkin tehdystä maininnasta ko. tiliin/ } \\
\text { käyttäjään. }\end{array}$ \\
\hline $\begin{array}{l}\text { Aihetunniste } \\
\text { (Hashtag \#) }\end{array}$ & $\begin{array}{l}\text { Aihetunniste } \\
\text { (Hashtag \#) }\end{array}$ & $\begin{array}{l}\text { Aihetunniste } \\
\text { (Hashtag \#) }\end{array}$ & $\begin{array}{l}\text { Aihetunnisteella viestejä ja julkaisuja voidaan } \\
\text { kategorisoida joukkoihin. }\end{array}$ \\
\hline $\begin{array}{l}\text { Live-lähetys } \\
\text { (Live) }\end{array}$ & & $\begin{array}{l}\text { Live-lähetys } \\
\text { (Live) }\end{array}$ & $\begin{array}{l}\text { Reaaliaikaisen suoran lähetyksen lähettämi- } \\
\text { nen seuraajajoukolle. Lähetyksen seuraajat } \\
\text { voivat osallistua videolla keskusteluun. }\end{array}$ \\
\hline $\begin{array}{l}\text { Tarina } \\
\text { (Story) }\end{array}$ & & $\begin{array}{l}\text { Tarina } \\
\text { (Story) }\end{array}$ & $\begin{array}{l}\text { Video- tai kuvapohjainen julkaisu, joka pois- } \\
\text { tuu nähtäviltä } 24 \text { tuntia julkaisemisen jälkeen } \\
\text { ja joka näkyy käyttäjän rajaamalle joukolle. } \\
\text { Tarinaan voi lisätä esimerkiksi filttereitä tai } \\
\text { musiikkia ja sen voi tallentaa itselleen. }\end{array}$ \\
\hline $\begin{array}{l}\text { Kommen- } \\
\text { tointi } \\
\text { (Comment) }\end{array}$ & & $\begin{array}{l}\text { Kommen- } \\
\text { tointi } \\
\text { (Comment) }\end{array}$ & $\begin{array}{l}\text { Viestien ja julkaisujen kommentointi. } \\
\text { Kommentti voi olla tekstin, videon, kuvan, } \\
\text { linkin tai muun alustakohtaisen toiminnon } \\
\text { muodossa. }\end{array}$ \\
\hline \multirow[t]{3}{*}{$\begin{array}{l}\text { Tallenna } \\
\text { (Saved) }\end{array}$} & & $\begin{array}{l}\text { Tallenna } \\
\text { (Saved) }\end{array}$ & Valitut julkaisut voi tallentaa kokoelmaksi. \\
\hline & & $\begin{array}{l}\text { IGTV } \\
\text { (IGTV) }\end{array}$ & $\begin{array}{l}\text { Pitkäkestoisten videoiden tallentamisen ja } \\
\text { katsomisen toiminto. }\end{array}$ \\
\hline & & $\begin{array}{l}\text { Kela } \\
\text { (Reels) }\end{array}$ & $\begin{array}{l}\text { Toiminto kuvien ja lyhyiden videoiden } \\
\text { editoimiseen ja jakamiseen. }\end{array}$ \\
\hline
\end{tabular}

Kun toimintoja tarkastelee lähemmin, huomaa, että eri toiminnot voivat yhdistyä toisiinsa. Esimerkiksi Instagramissa jako-toimintoon on mahdollista yhdistää tarina-toiminto: käyttäjä voi jakaa julkaisun tarina-toiminnossa. Toiminnot voi myös nähdä yksittäisinä moodeina tai multimodaalisina kokonaisuuksina, sillä yhdessä toiminnossa voi ilmetä useampi yksittäinen moodi: esimerkiksi kommentissa voi olla yhtä aikaa kuvaa ja tekstiä. Moodeiksi luetaan esimerkiksi kuvat, kirjoitukset, musiikki, eleet, puhe, liikkuva kuva, ääniraita sekä 3D-objektit, ja yhdessä useampi moodi muodostaa systeemin, jolloin niistä puhutaan multimodaalisina kokonaisuuksina (Kress 2010). Tarkemmin kuvattuna moodit ovat jaettuja semioottisia viestinnällisiä resursseja, joiden kautta muodostetaan ja ilmaistaan kulttuurisidonnaisia ja sosiaalisesti muokattuja merkityksiä (Hiippala 2017, 22; Kress 2010, 79, 87). Sosiaalisen median tapauksessa sen toiminnot puolestaan mahdollistavat käyttäjien välistä vuorovaikutusta, jonka kautta luodaan yhteisiä merkityksiä. Sosiaalisen median toiminnot voidaankin siis nähdä vuorovaikutusta mahdollistavina resursseina, joita moodit ilmentävät.

Multimodaalisuus rakentuu erilaisista moodien yhdistelmistä, joiden kautta luodaan merkityksiä. Moodeja voidaan tarkastella myös suhteessa 
toisiinsa, jolloin niiden nähdään rakentuvan ikään kuin toistensa päälle: on (pää)moodeja ja niille alisteisia alamoodeja. Stöckl (2004, 27) näkeekin, että multimodaalisten tekstien synnyssä moodit ja alamoodit sekoittuvat, sulautuvat ja muuttuvat lukemattomilla tavoilla. Lisäksi alamoodit nähdään osana modaalisuuksien hierarkiaa (Stöckl 2004), ja ne ovat eräänlaisia resursseja tai ilmaisuvaroja itse (pää)moodeille; esimerkiksi piirretyn kuvan (pää)moodina nähdään kuva ja sen alamoodeina viiva, kuvakulma, rajaaminen ja väri (ks. Nikula 2020, 350, 360). Elokuvalla voidaan puolestaan nähdä useampia (pää)moodeja - kuva, kieli, ääni ja musiikki - ja niillä alamoodeja kuten visuaaliset tehosteet, kuvakulma, äänen voimakkuus, nopeus ja rytmi (ks. Stöckl 2004, 13). Moodeja ja alamoodeja pohtiessa huomaakin, että myös sosiaalisen median keskustelut ovat täynnä erilaisia toisiinsa sekoittuvia multimodaalisia yhdistelmiä; kommentteja muodostetaan erilaisilla tekstin ja kuvan yhdistelmillä, jotka voivat olla sekä (pää)moodeja että alamoodeja tilanteesta ja tarkastelukulmasta riippuen.

Multimodaalisen näkökulman lisäksi teknologisia alustoja, kuten sosiaalisen median palveluja, ja siellä käytävää yhteiskunnallista keskustelua voidaan tarkastella affordanssien kautta; affordanssit mahdollistavat ja rajaavat verkon vuorovaikutteista toimintaa (Hutchby 2001). Alkuperäisessä merkityksessä affordanssin käsitteellä on haluttu kuvata havaintopsykologiassa sitä, minkälaisia (erilaisia ja useampia) käyttötapoja, tarjoumia, esimerkiksi kiven kaltaisella objektilla on; tarkemmin ottaen affordanssiksi on kutsuttu havaintoja objektin käyttötavasta (Gibson 1979, 1986). Käsitettä on sittemmin hyödynnetty kuvaamaan teknologioiden affordansseja (ks. esim. Hutchby 2001), ja nykyään myös sosiaalisen median palveluiden affordansseja (ks esim. boyd 2010; Treem \& Leonardi 2013). Tätä jälkimmäistä näkökulmaa on tutkinut muun muassa boyd (2010) verkottuneiden yleisöjen, julkisen sosiaalisen median, näkökulmasta. Hänen tutkimuksessaan sosiaalisen median affordansseina nähdään pysyvyys (persistence), toistettavuus (replicability), skaalattavuus (scalability/visibility) ja etsittävyys (searchability). Organisaatioiden sosiaalisen median näkökulmasta Treem ja Leonardi (2013) sekä Laitinen (2020) puolestaan nostavat esiin näkyvyyden (visibility), pysyvyyden (persistence), muokattavuuden (editability) ja yhdistävyyden (association) affordanssit. Organisaatioiden sosiaalisen median affordanssinäkökulmaa ei ole kehitetty varsinaisesti julkista sosiaalista mediaa varten, mutta sen voidaan kuitenkin ajatella soveltuvan sosiaalisen kollektiivisen toiminnan kuvaamiseen.

Kun ajatellaan sosiaalisen median palveluiden yksittäisiä toimintoja, nähdään sosiaalisen median affordanssit taustalla rajaavina ja mahdollistavina tekijöinä: esimerkiksi näkyvyyden affordanssin kautta julkiset viestit tehdään 
kaikille näkyviksi ja yksityisesti lähetettyjen viestien näkyvyys on puolestaan rajatumpaa. Pysyvyyden ansiosta viestit eivät poistu alustalta automaattisesti, mutta niiden esiintymisaikaa voidaan kuitenkin hallita. Muokattavuuden ansiosta viestejä on mahdollista editoida joissakin palveluissa julkaisun jälkeen, ja yhdistävyys mahdollistaa esimerkiksi uusien seuraajien tai kavereiden saamisen ja poistamisen omista verkostoista. Toistettavuus puolestaan mahdollistaa viestien duplikoimisen ja etsittävyys viestien löytämisen.

Eri alustat affordoivat eri tavoin viestitoimintoja. Esimerkiksi näkyvyyden affordanssia voidaan tarkastella erityisellä mielenkiinnolla tarina(stories)-toiminnoissa, joiden viestit katoavat 24 tunnin kuluttua julkaisusta. Näkyvyyden kannalta huomion arvoista on myös se, että visuaalisuutta korostavassa Instagram-palvelussa julkaisua ei voi muodostaa ilman kuvaa tai videota, kun taas Facebookissa ja Twitterissä voi tehdä myös pelkästään tekstiin nojaavan julkaisun. Alustojen toimintalogiikat ja affordanssit siis muokkaavat tässä tapauksessa käyttäjiä eri tavoin kuva- tai tekstiorientoituneiksi. Jos puolestaan tarkastellaan sosiaalisen median alustoja moodien ja multimodaalisen näkökulman kautta, nähdään näissä palveluissa paljon yhdistäviä tekijöitä; kaikissa palveluissa on joitain samoja moodeja ja alamoodeja. Kaikissa palveluissa voi esimerkiksi kommentoida, ja niissä voi jakaa ja julkaista kuvia, videoita ja tekstiä. Tämä on mielenkiintoista myös multimodaalisen tutkimuksen valossa, sillä esimerkiksi eri moodien välillä voidaan nähdä eroavaisuuksia: kuvia on helpompi muistaa ja havainnoida kuin kieltä, sillä kuvat ovat lähempänä elämäämme todellisuutta (Stöckl 2004, 17). Lisäksi joitakin moodeja voidaan suosia toisia enemmän, ja tämä on osittain kulttuurisidonnaista: esimerkiksi länsimaissa suositaan enemmän kirjoitusta kuin kuvia formaalissa julkisessa viestinnässä (Kress 2010, 83). Kuvan, tekstin ja muiden moodien suhdetta toisiinsa voi tarkastella myös kommenttien tutkimuksessa, sillä ne ilmenevät verkon multimodaalisessa ympäristössä.

Edellä mainittuun taustaan nojaten katsauksemme tarkoituksena on selvittää, kuinka sosiaalisen median kommentteja on tutkittu multimodaalisesta näkökulmasta digitaalisen journalismin ja poliittisen viestinnän tutkimuksen konteksteissa. Tässä katsauksessa kysymme:

TK1: Miten multimodaalisuus ja moodit on otettu huomioon tutkittaessa sosiaalisen median kommentteja digitaalisen journalismin ja poliittisen viestinnän tutkimuksessa, ja

TK2: millä tavoin näissä tutkimuksissa on rajattu ja perusteltu moodien valintoja? 
Yllä esittämämme taustoittavan teoriaosuuden sekä tutkimuskysymysten jälkeen tarkastelemme seuraavaksi tämän katsauksen aineistoa ja sen käsittelyä. Sen jälkeen kuvaamme, miten moodeja on tutkittu ja mahdollisesti perusteltu digitaalisen journalismin ja poliittisen viestinnän tutkimuksissa. Päätämme katsauksen pohdintaan ja huomioihin siitä, mikä merkitys moodeilla ja multimodaalisuudella on sosiaalisen median kommenttien tutkimuksessa.

\section{Katsauksen aineisto ja sen käsittely}

Katsauksemme aineisto muodostui viiden vuoden aikavälin (2015-2020) systemaattisesta kirjallisuuskatsauksesta. Se koostettiin kolmen journaalin Digital Journalism (630 artikkelia), Political Communication (201 artikkelia) ja Social Media + Society (1265 artikkelia) tietokannoista, joista käytiin läpi kaikki tutkimukset hakusanoilla Facebook (967), Twitter (863) ja Instagram (358). Näihin hakusanoihin ja journaaleihin päädyttiin, koska katsauksen tarkoituksena on nostaa esiin ne tutkimukset, joissa on tutkittu Facebookin, Twitterin ja Instagramin kommentteja digitaalisen journalismin ja poliittisen viestinnän konteksteissa.

Koostimme taulukkolaskentaohjelmaan ne tutkimusartikkelit, jotka täyttivät kriteerimme tähän katsaukseen soveltuvista sosiaalisen median kommenttien tutkimuksista. Katsausta ohjasivat kolme kriteeriä: 1) tutkimuksessa oli tarkasteltu Facebookia, Instagramia tai Twitteriä tai useampaa näistä; 2) tutkimus käsitteli digitaalista journalismia, poliittista viestintää tai molempia; 3) tutkimuksessa oli käytetty kommentteja aineistona. Twitterin tapauksessa kommentteihin laskettiin vastaustviitit (reply), uudelleentviittaukset (retweet/quote retweet) ja yksityisviestit (direct messages). Facebookin ja Instagramin kohdalla taas sisällytettiin sekä kommentointi (comments) että keskustelut (messenger) -toiminnot. Journaalihakuja tehdessä huomasimme, että osa hakutuloksista oli päällekkäisiä, sillä tutkimusartikkelit saattoivat sisältää mainintoja useammasta alustasta tai tutkia esimerkiksi sekä Facebookia että Twitteriä. Nämä käytiin alustavasti läpi ja kommentteja koskevat tutkimukset poimittiin lähempään tarkasteluun. Joissain tapauksissa oli vaikea määrittää, kuinka tarkasti kommentit oli sisällytetty analyysiin, sillä tutkimuksissa aineistoa saatettiin kuvata esimerkiksi sanoin "we took all the tweets [otimme kaikki tviitit]". Näissä tapauksissa tulkitsimme "kaikki tviitit" -ilmaisun sisältävän vähintäänkin uudelleentviittaukset.

Katsaukseen mukaan valikoituneita tutkimusartikkeleja tarkastelimme multimodaalisesta näkökulmasta, eli kartoitimme sitä, minkälaisia moodeja 
oli otettu huomioon kommenttien analysoimisessa ja miten niitä oli mahdollisesti rajattu ja perusteltu. Moodeja katsottiin sosiaalisen median toimintojen kautta, eli moodeille löytyy vastaavuus katsauksen teoria-osuudessa kuvatusta Facebookin, Twitterin ja Instagramin toiminnot -taulukosta (ks. Taulukko 1).

Analyysin alkuvaiheessa jaoimme kolmelle tutkijalle kaikki valitun ajanjakson artikkelit (2096 kappaletta). Tämän jälkeen keräsimme kriteerit täyttävät tutkimusartikkelit lähempään tarkasteluun. Tässä vaiheessa huomasimme, että useissa artikkeleissa käytettiin aineiston kuvauksen yhteydessä ilmauksia, joista oli vaikea määritellä, oliko kyseessä kommenttien tutkimus. Lisäksi moodien rajaukset ja perustelut olivat usein epäselvästi hahmotettavissa ja/tai ympäripyöreästi ilmaistu. Näistä kävimme yhteistä keskustelua ja täsmensimme tutkimusartikkelien valintakriteerejä. Osassa katsausta käytimme aineiston analysoinnin apuna Stöcklin (2004) mallia modaalisuuksien hierarkiasta ja Nikulan (2020) tutkimusta ristikkokuvien multimodaalisuudesta. Näitä aiempia tutkimuksia apuna käyttäen esittelemme tässä katsauksessa ajatuksen sosiaalisen median kommenttien tutkimuksen (pää)moodeista ja alamoodeista; avaamme asiaa lisää seuraavassa tulososiossa. Lisäksi kerromme seuraavaksi, miten ja mitä moodeja huomioitiin tässä katsauksessa mukana olevissa tutkimuksissa. Tarkastelemme myös tutkimuksien multimodaalisuuden astetta ja moodien valintojen rajaus- ja perustelutapoja.

\section{Tulokset}

Systemaattisen kirjallisuuskatsauksen tuloksena löysimme 2096 tutkimuksen joukosta 138 tutkimusta, joissa sosiaalisen median kommentit olivat analyysin kohteena. Tämä katsaus rajattiin digitaalisen journalismin ja poliittisen viestinnän tutkimuksiin, minkä vuoksi Digital Journalism ja Political Communication -journaaleiden tutkimuksien soveltuvuutta tähän katsaukseen ei tarvinnut juurikaan syvemmin pohtia. Social Media + Society -journaalissa puolestaan julkaistaan laajemminkin sosiaalisen median tutkimusta, minkä vuoksi kävimme katsaukseen valikoituneet sosiaalisen median kommentointia käsittelevät tutkimukset (138) uudelleen läpi kontekstikohtaisesti. Artikkelimäärä supistui, sillä mukana oli sellaisia tutkimuksia, jotka eivät olleet digitaalisen journalismin tai poliittisen viestinnän tutkimusta. Lopullinen katsaukseemme valikoitunut artikkelimäärä oli 66 tutkimusta (ks. liite 1): 26 digitaalisen journalismin tutkimusta, 34 poliittisen viestinnän tutkimusta sekä 6 tutkimusta, joissa ilmeni molemmat kontekstit. Nämä muodostivat lopullisen aineiston, jonka tulokset esittelemme seuraavaksi. Ensimmäi- 
seksi vastaamme tutkimuskysymykseen: Miten multimodaalisuus ja moodit on otettu huomioon tutkittaessa sosiaalisen median kommentteja digitaalisen journalismin ja poliittisen viestinnän tutkimuksessa?

Taulukossa 2 näkyy, kuinka moni artikkeli aineistossa käsitteli eri alustoja ja kuinka monessa artikkelissa tutkittiin eri moodeja. Sosiaalisen median alustoista ylivoimaisesti tutkituin sosiaalisen median kommenttien kontekstissa oli Twitter (57 tutkimusta), kun taas Facebookia (15 tutkimusta) ja Instagramia (1 tutkimus) oli tutkittu huomattavasti vähemmän. Kuudessa tutkimuksessa oli tutkittu sekä Twitteriä että Facebookia ja yksittäinen Instagram-tutkimus oli puolestaan yhteydessä Facebook- ja Twitter-tutkimukseen. Ns. puhtaita Twitter-tutkimuksia oli 50 ja puhtaita Facebook-tutkimuksia 9 kappaletta. Yksittäisiä moodeja tarkasteltaessa teksti oli ylivoimaisesti tutkituin (61 artikkelia) ja myös linkkejä (14), aihetunnisteita (12) sekä mainintoja (11) oli tutkittu jonkin verran. Vähemmälle huomiolle olivat puolestaan jääneet kuvat (8), videot (4) ja reaktiot (2). Tutkimusartikkelien moodien lukumäärä on Taulukossa 2 yhteenvetona. Yksittäisten moodien lukumäärät eivät täsmää taulukon yhteensä-riviin, sillä osassa tutkimuksissa aineistoon sisältyi useampi alusta ja tämän vuoksi osa moodeista on laskettu taulukossa mukaan useampaan kertaan.

Taulukko 2. Tutkimusartikkelit $(n=66)$ sosiaalisen median palvelujen ja moodien mukaan.

\begin{tabular}{|l|l|l|l|l|l|l|l|}
\hline Alusta & Teksti & $\begin{array}{l}\text { Hyper- } \\
\text { linkki }\end{array}$ & $\begin{array}{l}\text { Aihe- } \\
\text { tunniste }\end{array}$ & $\begin{array}{l}\text { Mai- } \\
\text { ninta }\end{array}$ & Kuva & Video & Reaktiot \\
\hline $\begin{array}{l}\text { Facebook } \\
(\mathrm{n}=16)\end{array}$ & 14 & 1 & 2 & 0 & 0 & 0 & 1 \\
\hline $\begin{array}{l}\text { Twitter } \\
(\mathrm{n}=57)\end{array}$ & 58 & 14 & 12 & 11 & 8 & 4 & 1 \\
\hline $\begin{array}{l}\text { Insta- } \\
\text { gram } \\
(\mathrm{n}=1)\end{array}$ & 1 & 0 & 0 & 0 & 0 & 0 & 0 \\
\hline $\begin{array}{l}\text { Yhteensä } \\
(\mathrm{n}=66)\end{array}$ & 73 & 15 & 14 & 11 & 8 & 4 & 2 \\
\hline
\end{tabular}

Taulukossa 2 näkyvät moodien määrät johdettiin sosiaalisen median palvelujen toimintojen (ks. Taulukko 1) ja katsauksen aineiston avulla. Tämän katsauksen havaintona on, että toimintojen kanssa yhteneviä sosiaalisen median kommenttien tutkimuksien moodeja ovat teksti, kuva, video, hyperlinkki, reaktiot, aihetunniste ja maininta. Aineistosta ilmeni yksittäisten moodien ja niiden kappalemäärien lisäksi tutkimuksien multimodaalisuuden aste. Multimodaalisia tutkimuksia, eli tutkimuksia joissa on analyysissä otettu 
huomioon vähintään kaksi moodia, löytyi aineistosta 31 kappaletta (ks. Taulukko 3). Tämä tarkoittaa sitä, että 35 tutkimuksessa oli otettu ainoastaan yksi moodi huomioon ja että 31 tutkimuksen kohdalla voidaan puhua multimodaalisesta tutkimuksesta ja niiden multimodaalisuuden asteesta. Lähempi moodien tarkastelu paljasti, että kaksi moodia oli huomioitu 15 tutkimuksessa, kolme moodia 12 tutkimuksessa, neljä moodia yhdessä, viisi moodia kahdessa ja kuusi yhdessä tutkimuksessa. Missään näistä tutkimuksista ei tutkittu Instagram-aineistoa, ja Facebook sisältyi vain viiteen tutkimukseen. Twitter-aineistojen määrä tutkimuksissa oli siis vallitseva. Multimodaaleista tutkimuksista (ks. Taulukko 3) suurin osa oli digitaalisen journalismin tutkimusta (18). Poliittisen viestinnän (7) ja molempia tutkimuskenttiä yhdistävää tutkimusta oli lähes yhtä paljon (6).

Taulukko 3. Tutkimusartikkelit ( $n=31$ ), joissa on enemmän kuin 2 moodia. Taulukossa merkintä " $X$ " tarkoittaa, että kyseinen moodi mainittiin analyysin kohteena. Konteksti DJ=digitaalinen journalismi, $P V=$ poliittinen viestintä, $M=$ molemmat. Alusta $T=$ Twitter (väri=valkoinen), $F B=$ Facebook (väri= vaaleanharmaa), $M=$ molemmat (väri=harmaa).

\begin{tabular}{|c|c|c|c|c|c|c|c|c|c|}
\hline $\begin{array}{l}\text { Tutkimus- } \\
\text { artikkelin } \\
\text { tiedot }\end{array}$ & $\begin{array}{l}\text { Kon- } \\
\text { teksti }\end{array}$ & Alusta & Teksti & Kuva & Video & $\begin{array}{l}\text { Hy- } \\
\text { per- } \\
\text { linkki }\end{array}$ & $\begin{array}{l}\text { Reak- } \\
\text { tiot }\end{array}$ & $\begin{array}{l}\text { Aihe- } \\
\text { tun- } \\
\text { niste }\end{array}$ & $\begin{array}{l}\text { Mai- } \\
\text { ninta }\end{array}$ \\
\hline Canter (2015) & DJ & $\mathrm{T}$ & $\mathrm{X}$ & $\mathrm{X}$ & & $\mathrm{X}$ & & & \\
\hline Vimieiro (2017) & DJ & $\mathrm{T}$ & $\mathrm{X}$ & & & & & $\mathrm{X}$ & \\
\hline $\begin{array}{l}\text { Rauchfleisch, } \\
\text { Vogler \& } \\
\text { Eisenegger } \\
(2020)\end{array}$ & DJ & $\mathrm{T}$ & $\mathrm{X}$ & & & $\mathrm{X}$ & & & \\
\hline Zhang (2018) & DJ & $\mathrm{T}$ & $\mathrm{X}$ & & & & & $\mathrm{X}$ & \\
\hline $\begin{array}{l}\text { Beckers \& } \\
\text { Harder (2016) }\end{array}$ & DJ & $\mathrm{T}$ & & & & $\mathrm{X}$ & & $\mathrm{X}$ & $\mathrm{X}$ \\
\hline Shermak (2018) & DJ & $\mathrm{T}$ & $\mathrm{X}$ & $\mathrm{X}$ & $\mathrm{X}$ & $\mathrm{X}$ & & & \\
\hline $\begin{array}{l}\text { Hanusch \& } \\
\text { Nölleke (2019) }\end{array}$ & DJ & $\mathrm{T}$ & $\mathrm{X}$ & & & & & & $\mathrm{X}$ \\
\hline $\begin{array}{l}\text { Kapidzic, Neu- } \\
\text { berger, Stieglitz } \\
\text { \& Mirbabaie } \\
\text { (2019) }\end{array}$ & DJ & $\mathrm{T}$ & $\mathrm{X}$ & & & $\mathrm{X}$ & & & $\mathrm{X}$ \\
\hline Olausson (2017) & DJ & $\mathrm{T}$ & $\mathrm{X}$ & $\mathrm{X}$ & & & & & \\
\hline Russell (2019) & DJ & $\mathrm{T}$ & $\mathrm{X}$ & $\mathrm{X}$ & $\mathrm{X}$ & $\mathrm{X}$ & & $\mathrm{X}$ & $\mathrm{X}$ \\
\hline $\begin{array}{l}\text { Masip, Ruiz \& } \\
\text { Suau (2019) }\end{array}$ & DJ & $\mathrm{T}$ & $\mathrm{X}$ & & & & & $\mathrm{X}$ & $\mathrm{X}$ \\
\hline $\begin{array}{l}\text { Maares, Lind } \\
\text { \& Greussing } \\
(2020)\end{array}$ & DJ & $\mathrm{T}$ & $\mathrm{X}$ & & & & & & $\mathrm{X}$ \\
\hline
\end{tabular}




\begin{tabular}{|c|c|c|c|c|c|c|c|c|c|}
\hline $\begin{array}{l}\text { Canter \& } \\
\text { Brookes (2016) }\end{array}$ & DJ & $\mathrm{T}$ & $\mathrm{X}$ & & & $\mathrm{X}$ & & $\mathrm{X}$ & $\mathrm{X}$ \\
\hline $\begin{array}{l}\text { Mourão, Diehl } \\
\text { \& Vasudevan } \\
(2016)\end{array}$ & DJ & $\mathrm{T}$ & $\mathrm{X}$ & & & $\mathrm{X}$ & & $\mathrm{X}$ & \\
\hline $\begin{array}{l}\text { Gómez-Zará \& } \\
\text { Diakopoulos } \\
\text { (2020) }\end{array}$ & DJ & $\mathrm{T}$ & $\mathrm{X}$ & $\mathrm{X}$ & & & & & \\
\hline $\begin{array}{l}\text { Kilgo, Lough \& } \\
\text { Riedl (2020) }\end{array}$ & DJ & M & $\mathrm{X}$ & & & & & $\mathrm{X}$ & \\
\hline $\begin{array}{l}\text { Rauchfleisch, } \\
\text { Artho, Metag, } \\
\text { Post \& Schäfer } \\
\text { (2017) }\end{array}$ & DJ & $\mathrm{T}$ & $\mathrm{X}$ & $\mathrm{X}$ & $\mathrm{X}$ & & & & \\
\hline Hedman (2016) & DJ & $\mathrm{T}$ & $\mathrm{X}$ & $\mathrm{X}$ & & $\mathrm{X}$ & & & \\
\hline $\begin{array}{l}\text { Groshek \& } \\
\text { Cutino (2016) }\end{array}$ & PV & $\mathrm{T}$ & $\mathrm{X}$ & & & & & & \\
\hline $\begin{array}{l}\text { Guerrero-Solé } \\
\text { (2018) }\end{array}$ & PV & $\mathrm{T}$ & $\mathrm{X}$ & & & & & $\mathrm{X}$ & \\
\hline Ceia (2020) & PV & $\mathrm{T}$ & & $\mathrm{X}$ & $\mathrm{X}$ & $\mathrm{X}$ & & & \\
\hline Schreiner (2018) & PV & $\mathrm{T}$ & $\mathrm{X}$ & & & $\mathrm{X}$ & & $\mathrm{X}$ & \\
\hline Maly (2019) & PV & FB & & & & $\mathrm{X}$ & $\mathrm{X}$ & & \\
\hline $\begin{array}{l}\text { Kligler-Vilen- } \\
\text { chik, Baden \& } \\
\text { Yarchi (2020) }\end{array}$ & PV & $\mathrm{M}$ & $\mathrm{X}$ & & & & & & \\
\hline $\begin{array}{l}\text { Sahly, Shao \& } \\
\text { Kwon (2019) }\end{array}$ & PV & $\mathrm{M}$ & $\mathrm{X}$ & & & & $\mathrm{X}$ & & \\
\hline $\begin{array}{l}\text { Harder, Paulus- } \\
\text { sen \& Van Aelst } \\
\text { (2016) }\end{array}$ & M & $\mathrm{T}$ & $\mathrm{X}$ & & & & & $\mathrm{X}$ & \\
\hline $\begin{array}{l}\text { Vobič, Maksuti \& } \\
\text { Deželan (2017) }\end{array}$ & M & $\mathrm{T}$ & $\mathrm{X}$ & & & $\mathrm{X}$ & & $\mathrm{X}$ & $\mathrm{X}$ \\
\hline Hasell (2021) & M & $\mathrm{T}$ & $\mathrm{X}$ & & & & & $\mathrm{X}$ & $\mathrm{X}$ \\
\hline $\begin{array}{l}\text { Carlson, } \\
\text { Robinson \& } \\
\text { Lewis (2020) }\end{array}$ & M & $\mathrm{T}$ & $\mathrm{X}$ & & & & & & $\mathrm{X}$ \\
\hline $\begin{array}{l}\text { Russell, } \\
\text { Hendricks, } \\
\text { Choi \& Conner } \\
\text { Stephens (2015) }\end{array}$ & M & $\mathrm{T}$ & $\mathrm{X}$ & & & $\mathrm{X}$ & & & $\mathrm{X}$ \\
\hline Jensen (2016) & M & M & $\mathrm{X}$ & & & & & $\mathrm{X}$ & \\
\hline Yhteensä, $n=31$ & & & 28 & 8 & 4 & 14 & 2 & 14 & 11 \\
\hline
\end{tabular}

Katsauksemme aineisto osoitti myös, että moodien suhteita toisiinsa on haastavaa määrittää: moodit ja alamoodit sekoittuvat, muuttuvat ja sulautuvat multimodaalisten tekstien synnyssä (Stöckl 2004, 27). Kommenttien tutkimuksessa, varsinkin kun tutkimuksien analyysejä on usein avattu heikosti, on hankala sanoa, mitkä moodit ovat alisteisia toisille, eli miten 
modaalisuuksien hierarkia (Stöckl 2004) rakentuu. Emme pysty tämän katsauksen aineiston perusteella tarkemmin erittelemään aineistomme (pää)moodien ja alamoodien suhteita toisiinsa eikä tällaista oltu tehty missään katsauksen tutkimusartikkelissa. Tämä erittely ei myöskään ole tutkimuskysymyksemme fokuksessa, sillä tutkimme miten moodit ja multimodaalisuus on otettu huomioon aiemmissa tutkimuksissa. Voimme kuitenkin todeta, että erilaisia moodeja löytyy tämän katsauksen tutkimuksista ja että aiempien tutkimuksien hierarkiajaotteluja apuna käyttäen (Stöckl 2004, 27; Nikula 2020, 350, 360) voimme johtaa sosiaalisen median kommenttien tutkimuksen kontekstiin soveltuvan yleispätevän moodien hierarkian (ks. Kuvio 1). Tässä hierarkiassa näemme (pää)moodeina tekstitason sekä kuva- ja videotason moodit. Tekstitason alamoodeiksi voidaan laskea teksti, hyperlinkki, aihetunniste ja maininta. Kuva- ja videotason alamoodeiksi lasketaan puolestaan kuva, video ja reaktiot. Kaikki nämä moodit nojaavat moodien hierarkian (Stöckl 2004) ja aiemman tutkimuksen (Nikula 2020) lisäksi sosiaalisen median alustojen toimintoihin sekä aineistomme analyysiin. Toteamme siis, että näitä (pää)moodeja ja alamoodeja ilmenee aineistossamme, mutta niiden suhdetta toisiinsa on mahdotonta selvittää tällä aineistolla, osittain johtuen tutkimusartikkeleissa raportoidun analyysin epätarkasta avaamisesta.

(Pää)moodit

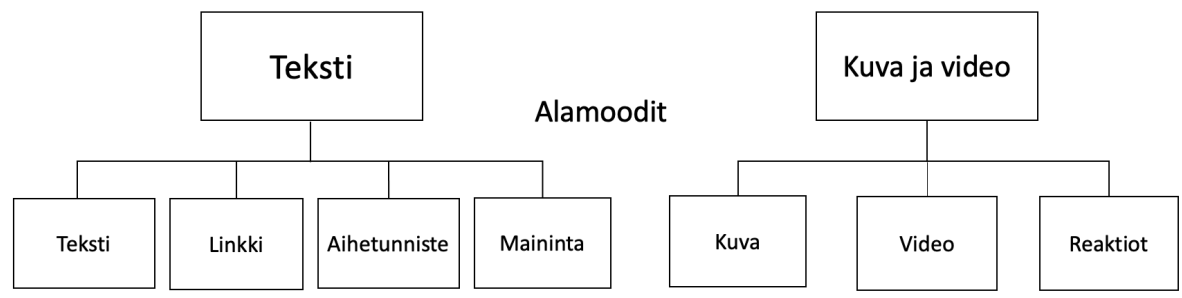

Kuvio 1. Sosiaalisen median kommenttien tutkimuksen moodien hierarkia: (pää)moodit ja alamoodit.

Toinen tutkimuskysymyksemme kohdistui moodien rajauksiin ja moodivalintojen perusteluihin: Millä tavoin näissä tutkimuksissa on rajattu ja perusteltu moodien valintoja? Kirjallisuuskatsauksessamme löytyi vain kymmenen tutkimusta, joissa moodien rajausta perusteltiin jollakin tavalla. Kaikkien näiden kymmenen tutkimuksen aineistot muodostuivat Twitteraineistoista, ja niitä oli perusteltu kolmella eri tavalla: moodien sisällyttämisen tapa, moodien pois rajaamisen tapa ja menetelmän ohjaama tapa moodirajauksessa. Viidessä tutkimuksessa ilmaistiin suoraan, mitä moodeja sisälly- 
tettiin analyysiin (Nuernbergk 2016; Guerrero-Solé 2018; McGregor \& Mourão 2016; Schreiner 2018; Russell 2019), ja yhdessä tutkimuksessa moodien sisällyttäminen ilmaistiin niputtamalla kaikki moodit yhteen (Canter \& Brookes 2016). Pois rajaamista käsiteltiin kahdessa tutkimuksessa (Canter 2015; Yantseva 2019), joissa rajattiin tietyt moodit analyysin ulkopuolelle. Menetelmän ohjaama tapa näkyi kahdessa tutkimuksessa, joissa toisessa rajaus ilmaistiin keskittymisellä tekstianalyysiin (Carlson, Robinson \& Lewis 2020) ja toisessa aineiston keräystapa rajoitti aineiston tekstiksi (Bastos \& Farkas 2019).

Moodien sisällyttämistä ilmaisevissa kuudessa tutkimuksessa sisällyttäminen kerrottiin joko artikkelin tavoitteen, aineiston keräyksen tai analyysimenetelmän yhteydessä. Esimerkiksi Nuernbergkin (2016) tutkimuksessa moodien analyysiin sisällyttäminen selvisi kirjoittajan avatessa menetelmän yhteydessä koodikehystään, jossa yhdessä kohdassa oli suluissa mainittu hyperlinkit, aihetunnisteet, vastaukset ja uudelleentviittaukset. Muista tutkimuksen analyysin kohdista pystyi lisäksi tulkitsemaan, että kirjoittaja analysoi tekstiä ja mainintoja, koska kyseisissä kohdissa oli avattu tekstin sisältöä ja mainintoja. Schreiner (2018) taas ilmaisi oman tavoitteensa kohdalla olevansa kiinnostunut tviittien aiheesta, sävystä ja viestintätavoista ja lisäsi suluissa myös maininnat, uudelleentviittaukset, linkit, aihetunnisteet ja lähdetietojen ilmaisut. Aineiston keräämisen kautta moodien sisällyttämisen ilmaisi Guerrero-Solé (2018), joka listasi tviitin sisällön, aihetunnisteet ja maininnat aineiston keräyksen kohteiksi. Vastaavalla tavalla McGregor \& Mourão (2016) kuvailivat sisällyttäneensä aineistoonsa myös aihetunnisteet ja maininnat. Russell (2019) ilmaisi tekstissä sisällyttäneensä analyysissään tviittien luokitteluun tekstin, hyperlinkit, kuvat, videot, maininnat, uudelleentviittaukset ja aihetunnisteet, mutta jättäneensä käsittelystä pois linkit ja maininnat koska niitä oli hänen aineistossaan vain yhdessä prosentissa kaikista tviiteistä. Nämä kuitenkin oli aluksi sisällytetty aineistoon, joten laskimme ne kuuluvaksi kategoriaan, jossa moodeja lähestyttiin aineiston sisällyttämisen perustelutavalla. Canter ja Brookes (2016) niputtivat kaikki moodit yhteen toteamalla, että tviitit sisälsivät tekstiä, kuvia ja ilmauksia, ja että sisällönanalyysi tehtiin tviiteille. He eivät siis rajanneet eri moodeja tai ilmaisseet, että niitä tulisi analysoida eri tavoilla. Tutkimuksen moodeista kuitenkin rajattiin hyperlinkit ja maininnat analyysin ulkopuolelle niiden vähäisen määrän vuoksi. Koska rajaus tehtiin vasta keräyksen ja ensimmäisen analyysivaiheen jälkeen ja sitä perusteltiin kyseisten moodien vähäisellä määrällä, laskimme tutkimuksen kuuluvaksi moodien sisällyttämisen perustelutapaan.

Moodien pois rajauksen kautta analyysin kohteita puolestaan kuvailtiin kahdessa tutkimusartikkelissa. Yantseva (2020) kuvasi sulkeneensa aineiston 
ulkopuolelle kaikki alle kolme sanaa sisältäneet tviitit ja uudelleentviittaukset, vaikka niissä olisi ollut mainintoja, linkkejä ja aihetunnisteita. Canter (2015) taas ilmaisi rajauksen yhteydessä, että aihetunnisteet oli rajattu pois aineistosta. Viimeisen eli menetelmän ohjaaman tavan kohdalla jäi lukijalle tulkittavaksi, että eri moodit rajautuivat pois valittujen menetelmien, eli tekstianalyysin (Carlson, Robinson \& Lewis 2020), ja tekstiin rajoittuvan keräystavan (Bastos \& Farkas 2019) vuoksi. Näissä tapauksissa ei siis ilmaistu erikseen mitä sisällytettiin tai rajattiin pois, vaan moodien valinta oli luettavissa tekstiin fokusoitumisesta, jolloin oli tulkittavissa että esimerkiksi visuaalinen sisältö rajautui pois.

\section{Lopuksi}

Tämän katsauksen kautta saatiin lisää tietoa sosiaalisen median kommenttien tutkimuksesta ja siitä, kuinka eri moodeja ja multimodaalisuutta on otettu, ja voidaan ottaa, huomioon sosiaalisen median kommenttien tutkimuksessa. Katsaus myös tarkasteli multimodaalisten tutkimuksien aineiston rajaamista ja näiden rajausten perusteluja. Lisäksi katsaus tuotti tietoa siitä, kuinka paljon sosiaalisen median kommentointia on tutkittu digitaalisen journalismin ja poliittisen viestinnän kentillä Facebookin, Twitterin ja Instagramin kontekstissa.

Katsauksessa havaittiin systemaattista kirjallisuuskatsausta hyödyntäen, että ylipäänsä sosiaalisen median kommenttien tutkimus oli vähäistä Digital Journalism, Political Communication ja Social Media + Society -journaaleissa: yli 2000 tutkimuksesta 138:ssa tutkittiin kommentteja. Määrä on vielä vähäisempi, kun sitä tarkastellaan tämän katsauksen rajauksen kautta: digitaalisen journalismin ja poliittisen viestinnän kontekstissa sosiaalisen median kommenttien tutkimusta ilmeni ainoastaan 66 tutkimuksessa. Määrä pieneni entisestään, kun tarkasteltiin tutkimuksia multimodaalisesta näkökulmasta. Ainoastaan 31 tutkimusta voitiin kutsua multimodaaliseksi tutkimukseksi, eli näissä tutkimuksissa oli huomioitu vähintään kaksi moodia. Yli kahden ja kolmen moodin tutkimukset olivat harvinaisia, eli multimodaalisuuden aste ei ollut kovinkaan korkea suuressa osassa tämän katsauksen 66 artikkelissa. Alustoista sosiaalisen median kommenttien tutkimus oli suurinta Twitterissä, ja näin oli myöskin moodien ja multimodaalisuuden näkökulmasta. Lisäksi tutkimuksien aineistojen rajauksien perusteluja oli mainittu ainoastaan Twitter-tutkimuksissa.

Kress $(2010,83)$ on nostanut esiin, että tiettyjä moodeja voidaan suosia eri konteksteissa, ja tämä näkyy myös katsauksemme tuloksissa. Syynä tälle voi olla sosiaalisen median tutkimuksen keräystapojen ja aineiston käsittelyn 
haastavuus tiettyjen moodien kohdalla tai esimerkiksi tekstin korostuminen viestinnän muotona tähän katsaukseen valituissa konteksteissa. Kun tarkasteltiin katsauksen tuloksia (pää)moodeittain, havaittiin, että tutkimuksissa oli huomioitu enemmän tekstitason kuin kuva- ja videotason moodeja. (Pää)moodien ja alamoodien tarkempia suhteita toisiinsa ei pystytty tämän katsauksen aineiston perusteella määrittelemään. Tällaiselle tutkimukselle olisi tarve, sillä siten voitaisiin hahmottaa miten (pää)moodit ja alamoodit muodostuvat sosiaalisen median ja kommenttien tutkimuksien kontekstissa. Pystyimme kuitenkin tutkimaan hieman enemmän kuin yksittäisiä moodeja, joita on jo hyvin tutkittu (Stöckl 2004, 10), sillä pystyimme tarkastelemaan tutkimusten multimodaalisuuden astetta, joka ei ollut useassa artikkelissa kovin korkea. Lisäksi esittelimme aiemman teorian (Stöckl 2004; Nikula 2020) ja tämän katsauksen analyysin avulla sosiaalisen median kommenttien tutkimuksen moodien hierarkian, minkä toivommekin inspiroivan jatkotutkimusta. Esimerkiksi juuri sosiaalisen median kommenttien moodien suhteita ja alisteisuutta toisiinsa voisi tarkastella moodien hierarkian tasolla. Erityisen mielenkiintoinen tutkimuskohde olisi Instagram, sillä siellä ei voi esimerkiksi julkaista syötteessä julkaisuun kommenttina kuvaa tai videota; alusta mahdollistaa julkaisuun tehtävän kommentin ainoastaan tekstin ja hymiöiden muodossa.

Sosiaalisen median affordanssien (ks. esim. Hutchby 2001) näkökulmasta moodit (vrt. sosiaalisen median toiminnot) ovat olennainen osa sitä, miten sosiaalisen median keskustelut järjestäytyvät ja millä tavalla niissä voidaan ilmaista itseä, olla vuorovaikutuksessa toisten kanssa sekä rakentaa julkista keskustelua. Esimerkiksi näkyvyyden affordanssin näkökulmasta ihmisten sosiaalisen median keskusteluihin jättämien kommenttien pysyvyydellä ja pysymättömyydellä on suuri vaikutus keskustelujen kulkuun ja tätä myötä yhteiskunnalliseen keskusteluun. Tämän katsauksen aineistosta ei noussut esiin yhtään moodia/sosiaalisen median toimintoa, joka olisi hetkellinen, kuten vaikkapa Facebookissa tai Instagramissa 24 tuntia näkyvillä oleva tarina (story). Tällaisten hetkellisten moodien tarkastelu olisikin mielenkiintoista erityisesti näkyvyyden affordanssin näkökulmasta, sillä se on nostettu jopa eräänlaiseksi juuri-affordanssiksi, joka vaikuttaa muiden affordanssien taustalla (Treem, Leonardi \& van den Hooff 2020). Lisäksi multimodaalisuuden näkökulmasta muokattavuuden affordanssin tarkastelu voisi osoittautua mielenkiintoiseksi. Muokattavuuden vuoksi jotkut analyysin yksikkönä olevat moodit ovat voineet poistua tai ne on voitu poistaa aineistosta, ennen kuin tutkija on saanut aineistonsa kerättyä. Tällöin tutkijan keräämä aineisto ei olekaan niin autenttinen, kuin se on jossain vaiheessa sosiaalisen median alustalla ollut. 
Moodien rajausta perusteltiin ainoastaan kymmenessä artikkelissa, mikä viittaa siihen, että moodien merkitystä ei välttämättä täysin ymmärretä analysoitaessa sosiaalisen median aineistoja. Näistä kymmenestä tutkimuksesta, joista löytyi moodien rajaukselle jokin perustelu, pystyttiin erottamaan kolme perustelutapaa. Näistä yleisin oli moodien sisällyttäminen, jolloin kerrottiin, mitä tutkimuksiin otettiin mukaan. Toiseksi yleisin sellainen, joka ilmaisi mitä tutkimuksista oli rajattu pois. Lisäksi kahdessa tutkimuksessa menetelmä ohjasi moodien valintoja. Toisessa tekstianalyysi menetelmänä selitti muiden moodien pois rajaamisen ja toisessa valittu keräystapa sisällytti aineistoon vain tekstin. Rajauksen perusteluja tai mainintoja rajauksista oli näiden vaihtelevien ilmaisutapojen vuoksi haastava löytää artikkeleista. Moodien sisällyttämistä tai pois rajaamista käsiteltiin tutkimuksissa hyvin eri tavalla ja tulisikin miettiä, onko moodien luetteleminen tai perusteellisempi aukikirjoittaminen ja perustelu olennainen osa sosiaalisen median aineistojen kuvausta tutkimuksissa. Tämä ei vielä välttämättä ratkaisisi Stöcklin (2004, 10) ehdottamaa tarvetta ymmärtää miten moodit järjestäytyvät ja vuorovaikuttavat teksteissä, mutta se voisi tuoda meitä lähemmäs ajatusta siitä, että moodit ymmärrettäisiin erillisinä ja eri tavalla, järjestäytyvinä, mutta keskenään yhteydessä olevina, viestinnällisinä resursseina eri tutkimuskonteksteissa.

Aineistojen rajausten perusteluissa ongelmallista oli etenkin se, että useamman tutkimuksen kohdalla oli vaikea määrittää, oliko kyse kommenttien tutkimuksesta. Kun artikkelin aineisto kuvattiin esimerkiksi "we took all the tweets [otimme kaikki tviitit]”, jäi epäselväksi, mitä kaikkea aineistoon sisältyi. Näissä tapauksissa sisällytimme artikkelit kuitenkin aineistoon, sillä tulkitsimme "kaikki tviitit" -ilmaisun sisältävän vähintäänkin uudelleentviittaukset. Haasteita oli myös moodien rajausten sekä perustelujen löytämisessä, ja jatkotutkimusmahdollisuuksia aiheesssa onkin useita. Koska eettiset kysymykset kuten anonymiteetin säilyminen kommentteja tutkittaessa ja julkisen tilan käsitteen kyseenalaistaminen sosiaalisen median kirjoitusten kohdalla ovat lisääntyneet (ks. esim. Turtiainen \& Östman 2013, 49-67), olisi tärkeä saada myös lisää näkökulmia sosiaalisen median kommenttien tutkimuksen eettiseen puoleen.

Verkkokeskusteluja käsittelevän tutkimuksen lisääntyessä on kiistatonta, että siihen liittyy haasteita erityisesti aineistoihin liittyvien eettisten kysymysten mutta myös aineistojen moninaisuuden vuoksi. Koska sosiaalisen median tutkimuskenttä on laaja, on tärkeää pysähtyä pohtimaan, miten eri aineistovalinnat vaikuttavat tutkimukseen, sekä mitä yksittäisestä päivityksestä tai kommentista sisällytetään analyysiin ja mitä rajataan ulkopuolelle. Nämä valinnat vaikuttavat merkittävästi siihen, mitä voimme tutkijoina saada irti 
sosiaalisen median kommentteja tutkimalla. Toivommekin, että tämä katsaus herättää tutkijoita tarkastelemaan tarkemmassa valossa kommenttien tutkimusta, ja laajemmin sosiaalisen median tutkimuksen multimodaalista näkökulmaa. Tällä tavalla tutkijat voisivat tehdä moodien osalta tietoisia valintoja aineiston rajauksissa ja niiden perusteluissa.

\section{Kiitokset}

Haluamme kiittää vierailevia toimittajia Salla-Maaria Laaksosta, Thomas Olssonia sekä Jesse Haapojaa heidän arvokkaista kommenteistaan ja panoksestaan katsauksen loppuun saattamiseksi. Kiitämme myös Jyväskylän yliopiston journalistiikan tohtoriseminaaria ja sen vetäjää Lauri Haapasta heidän hyvistä huomioistaan.

\section{Lähteet}

Bossetta, M. (2018). The Digital Architectures of Social Media: Comparing Political Campaigning on Facebook, Twitter, Instagram, and Snapchat in the 2016 U.S. Election. Journalism \& Mass Communication Quarterly, 95(2), 471-496. https://doi.org/10.1177/1077699018763307

Boulianne, S. (2015). Social media use and participation: a meta-analysis of current research. Information, Communication \& Society, 18(5), 524-538. https://doi.org/10.1080/136911 8X.2015.1008542

boyd, d. m. (2010). Social Network Sites as Networked Publics: Affordances, Dynamics, and Implications. Teoksessa Z. Papacharissi (toim.), Networked self: Identity, community, and culture on social network sites (s. 39-58). Routledge.

Bruns, A. (2018). Gatewatching and news curation: Journalism, social media, and the public sphere. Digital Formations, 113. Peter Lang Publishing.

Chen, G. M., \& Pain, P. (2017). Normalizing Online Comments. Journalism Practice, 11(7), 876892. https://doi.org/10.1080/17512786.2016.1205954

Debus, M., Stuckenschmidt, H., \& Wessler, H. (2015). On the use of different modalities in political communication: Evidence from German election manifestos. Teoksessa J. Wildfeuer (toim.), Building bridges for multimodal research. International perspectives on theories and practices of multimodal analysis (s. 211-225). Peter Lang.

Djonov, E., \& Van Leeuwen, T. (2018). Social media as semiotic technology and social practice: the case of ResearchGate's design and its potential to transform social practice. Social Semiotics, 28(5), 641-664. https://doi.org/10.1080/10350330.2018.1504715

Haasio, A., Mattila, M., Ojanperä, A., \& Kannasto, E. (2018). Terrori-isku tiedontarpeiden virittäjänä: Turun puukotusten aiheuttamat tiedontarpeet. Informaatiotutkimus, $37(2)$. https://doi.org/10.23978/inf.71157 
Harju, A. A., \& Huhtamäki, J. (2021) ‘\# hellobrother needs to trend’: methodological reflections on the digital and emotional afterlife of mediated violence. International Review of Sociology, 31(2), 310-341. https://doi.org/10.1080/03906701.2021.1947951

Hiippala, T. (2017). The multimodality of digital longform journalism. Digital journalism, 5(4), 420-442. https://doi.org/10.1080/21670811.2016.1169197

Kahne, J., \& Bowyer, B. (2018). The Political Significance of Social Media Activity and Social Networks. Political Communication, 35(3), 470-493. https://doi.org/10.1080/10584609.2018. 1426662

Kannasto, E. (2020). Personal Brand of a Politician in an Election Campaign - Political Personas on Facebook. Persona Studies, 6(1), 12-14. https://doi.org/10.21153/psj2020vol6no1art943

Kim, Y., \& Chen, H.-T. (2016). Social media and online political participation: The mediating role of exposure to cross-cutting and like minded perspectives. Telematics and Informatics, 33, 320-330. https://doi.org/10.1016/j.tele.2015.08.008

Kress, G. (2010). Multimodality. A Social Semiotic Approach to Contemporary Communication. Routledge.

Laaksonen, S.-M. \& Pöyry, E. (2018). Pahastumista vai politiikkaa: Sosiaalisen median kohut affektiivisessa keskustelukulttuurissa. WiderScreen, 21(3). Haettu 25.10.2021 http: // widerscreen.fi/numerot/2018-3/pahastumista-vai-politiikkaa-sosiaalisen-mediankohut-affektiivisessa-keskustelukulttuurissa/

Marchionni, D. M. (2013. Journalism-as-a-Conversation: A Concept Explication. Communication Theory, 23, 131-147. https://doi.org/10.1111/comt.12007

Markham, A., \& Buchanan, E. (2017). Research Ethics in Context. Decision-Making in Digital Research. Teoksessa M. T. Schäfer \& K. van Es (toim.), The Datafied Society. Studying Culture through Data. Amsterdam University Press.

McNair, B. (2003). An Introduction to Political Communication (3rd ed). Routledge.

Newman, N., Fletcher, R., Schulz, A., Andi, S., \& Nielsen, R. K. (2020). Reuters Institute Digital News Report 2020. Haettu 23.8.2021 https://reutersinstitute.politics.ox.ac.uk/sites/ default/files/2020-06/DNR_2020_FINAL.pdf

Nikula, S. (2020). Viivoihin vangitut: ristikkokuvien ilmaisukeinot ja vihjeiden ymmärtäminen sosiosemiotiikan näkökulmasta. Media \& viestintä, 43(4), 345-365. https : //doi .org/10.23983/ $\mathrm{mv} .100620$

Pettersson, K. \& Sakki, I. (2020) Analysing Multimodal Communication and Persuasion in Populist Radical Right Political Blogs. Teoksessa M. A. Demasi, S. Burke, C. Tileagă (toim.), Political Communication. Palgrave Studies in Discursive Psychology. Palgrave Macmillan. https://doi.org/10.1007/978-3-030-60223-9_7

Pink, S., Ruckenstein, M., Willim, R., \& Duque, M. (2018). Broken data: Conceptualising data in an emerging world. Big Data \& Society, 5(1), https://doi.org/10.1177/2053951717753228

Rantasila, A. (2018). Tahmaiset affektit. Fukushima Daiichin ydinonnettomuus YLE:n uutisoinnin verkkokommenteissa. Lähikuva, 31(3), 30-45. https://doi.org/10.23994/1k.76570

Salonen, M., Olbertz-Siitonen, M., Uskali, T., \& Laaksonen, S.-M. (in review). Conversational gatekeeping - Social interactional practices of post-publication gatekeeping. 
Steensen, S., Grøndahl Larsen, A. M., Benestad Hågvar, Y., \& Kjos Fonn, B. (2019). What Does Digital Journalism Studies Look Like? Digital Journalism, 7(3), 320-342. https: //doi .org/ 10.1080/21670811.2019.1581071

Stöckl, H. (2004). In between modes. Language and image in printed media. Teoksessa E. Ventola, C. Cassily, \& M. Kaltenbacher (toim.), Perspectives on Multimodality (s. 9-30). John Benjamins Publishing Company. https://doi.org/10.1075/ddcs.6.03sto

Suominen, J., Saarikoski, P., \& Vaahensalo, E. (2019). Digitaalisia kohtaamisia. Verkkokeskustelut BBS-purkeista sosiaaliseen mediaan. Gaudeamus.

Tieteen termipankki. 23.8.2021. Kielitiede:kielellinen merkki. Haettu 23.8.2021 https:// tieteentermipankki.fi/wiki/Kielitiede:kielellinen_merkki

Treem, J. W., Leonardi, P. M., \& van den Hooff, B. 2020. Computer-mediated communication in the age of communication visibility. Journal of Computer-Mediated Communication, 25(1), 44-59. https://doi.org/10.1093/jcmc/zmz024

Turtiainen, R. \& Östman, S. (2013). Verkkotutkimuksen eettiset haasteet: Armi ja anoreksia. Teoksessa S.-M. Laaksonen, J. Matikainen \& M. Tikka (toim.), Otteita Verkosta (s. 49-67). Vastapaino. 


\section{LIITE 1. Tutkimusartikkeliaineisto, $n=66$}

\section{Artikkelit: Digital Journalism, $\mathbf{n}=\mathbf{2 7}$}

Beckers, K., \& Harder, R. A. (2016). “Twitter Just Exploded”. Digital Journalism, 4(7), 910-920. https://doi.org/10.1080/21670811.2016.1161493

Bennett, D. (2016). Sourcing the BBC's Live Online Coverage of Terror Attacks. Digital Journalism, 4(7), 861-874. https://doi.org/10.1080/21670811.2016.1163233

Brems, C., Temmerman, M., Graham, T., \& Broersma, M. (2017). Personal Branding on Twitter. Digital Journalism, 5(4), 443-459. https://doi.org/10.1080/21670811.2016.1176534

Canter, L. (2015). Personalised Tweeting. Digital Journalism, 3(6), 888-907. https://doi.org/ 10.1080/21670811.2014.973148

Canter, L., \& Brookes, D. (2016). Twitter as a Flexible Tool. Digital Journalism, 4(7), 875-885. https://doi.org/10.1080/21670811.2016.1168707

Carlson, M., Robinson, S., \& Lewis, S. C. (2021). Digital Press Criticism: The Symbolic Dimensions of Donald Trump's Assault on U.S. Journalists as the "Enemy of the People". Digital Journalism, 9(6), 737-754. https://doi.org/10.1080/21670811.2020.1836981

Cleary, J., al Nashmi, E., Bloom, T., \& North, M. (2015). Valuing Twitter. Digital Journalism, 3(6), 908-924. https://doi.org/10.1080/21670811.2014.990255

Ford, H., \& Hutchinson, J. (2019). Newsbots That Mediate Journalist and Audience Relationships. Digital Journalism, 7(8), 1013-1031. https://doi.org/10.1080/21670811.2019.1626752

Gómez-Zará, D., \& Diakopoulos, N. (2020). Characterizing Communication Patterns between Audiences and Newsbots. Digital Journalism, 8(9), 1093-1113. https://doi.org/10.1080/ 21670811.2020.1816485

Hanusch, F., \& Nölleke, D. (2019). Journalistic Homophily on Social Media. Digital Journalism, 7(1), 22-44. https://doi.org/10.1080/21670811.2018.1436977

Harder, R. A., Paulussen, S., \& Van Aelst, P. (2016). Making Sense of Twitter Buzz. Digital Journalism, 4(7), 933-943. https://doi.org/10.1080/21670811.2016.1160790

Hasell, A. (2021). Shared Emotion: The Social Amplification of Partisan News on Twitter. Digital Journalism, 9(8), 1085-1102. https://doi.org/10.1080/21670811.2020.1831937

Jensen, M. (2016). The Emergence of Second-Screen Gatekeeping. Digital Journalism, 4(3), 321338. https://doi.org/10.1080/21670811.2015.1054408

Kapidzic, S., Neuberger, C., Stieglitz, S., \& Mirbabaie, M. (2019). Interaction and Influence on Twitter. Digital Journalism, 7(2), 251-272. https://doi.org/10.1080/21670811.2018.1522962

Kilgo, D. K., Lough, K., \& Riedl, M. J. (2020). Emotional appeals and news values as factors of shareworthiness in Ice Bucket Challenge coverage. Digital Journalism, 8(2), 267-286. https://doi.org/10.1080/21670811.2017.1387501

Lindgren, A., Corbett, J., \& Hodson, J. (2020). Mapping Change in Canada's Local News Landscape: An Investigation of Research Impact on Public Policy. Digital Journalism, 8(6), $758-$ 779. https://doi.org/10.1080/21670811.2020.1724516

Maares, P., Lind, F., \& Greussing, E. (2021). Showing off Your Social Capital: Homophily of Professional Reputation and Gender in Journalistic Networks on Twitter. Digital Journalism, 9(4), 500-517. https://doi.org/10.1080/21670811.2020.1835513 
Masip, P., Ruiz, C., \& Suau, J. (2019). Contesting Professional Procedures of Journalists: Public Conversation on Twitter after Germanwings accident. Digital Journalism, 76), 762782. https://doi.org/10.1080/21670811.2018.1546551

Mourão, R., Diehl, T., \& Vasudevan, K. (2016). I Love Big Bird. Digital Journalism, 4(2), 211-228. https://doi.org/10.1080/21670811.2015.1006861

Olausson, U. (2017). The Reinvented Journalist. Digital Journalism, 5(1), 61-81. https://doi. org/10.1080/21670811.2016.1146082

Rauchfleisch, A., Vogler, D., \& Eisenegger, M. (2020). Transnational News Sharing on Social Media: Measuring and Analysing Twitter News Media Repertoires of Domestic and Foreign Audience Communities. Digital Journalism, 8(9), 1206-1230. https://doi.org/10.1080/216 70811.2020.1835511

Russell, F. M. (2019). Twitter and News Gatekeeping. Digital Journalism, 7(1), 80-99. https:// doi.org/10.1080/21670811.2017.1399805

Russell, F. M., Hendricks, M. A., Choi, H., \& Stephens, E. C. (2015). Who Sets the News Agenda on Twitter? Digital Journalism, 3(6), 925-943. https://doi.org/10.1080/21670811.2014.995918

Shermak, J. L. (2018). Scoring Live Tweets on the Beat. Digital Journalism, 6(1), 118-136. https://doi.org/10.1080/21670811.2017.1338144

Vimieiro, A. C. (2017). Sports Journalism, Supporters and new Technologies. Digital Journalism, 5(5), 567-586. https://doi.org/10.1080/21670811.2016.1263161

Vobič, I., Maksuti, A., \& Deželan, T. (2017). Who Leads the Twitter Tango? Digital Journalism, 5(9), 1134-1154. https://doi.org/10.1080/21670811.2016.1259002

Zhang, X. (2018). Visualization, Technologies, or the Public? Digital Journalism, 6(6), 737-758. https://doi.org/10.1080/21670811.2017.1340094

\section{Artikkelit: Political Communication, $n=6$}

Baldwin-Philippi, J. (2020). Data Ops, Objectivity, and Outsiders: Journalistic Coverage of Data Campaigning. Political Communication, 37(4), 468-487. https://doi.org/10.1080/10584609 .2020 .1723751

Ketelaars, P., \& Sevenans, J. (2021). It's a Matter of Timing. How the Timing of Politicians' Information Subsidies Affects What Becomes News. Political Communication, 38(3), 260280. https://doi.org/10.1080/10584609.2020.1763528

Kligler-Vilenchik, N., de Vries Kedem, M., Maier, D., \& Stoltenberg, D. (2021). Mobilization vs. Demobilization Discourses on Social Media. Political Communication, 38(5), 561-580. https://doi.org/10.1080/10584609.2020.1820648

Linvill, D. L., \& Warren, P. L. (2020). Troll Factories: Manufacturing Specialized Disinformation on Twitter. Political Communication, 37(4), 447-467. https://doi.org/10.1080/10584609.2 020.1718257

Margolin, D. B., Hannak, A., \& Weber, I. (2018). Political Fact-Checking on Twitter: When Do Corrections Have an Effect? Political Communication, 35(2), 196-219. https://doi.org/10. 1080/10584609.2017.1334018

Muddiman, A., McGregor, S. C., \& Stroud, N. J. (2019). (Re)Claiming Our Expertise: Parsing Large Text Corpora With Manually Validated and Organic Dictionaries. Political Communication, 36(2), 214-226. https://doi.org/10.1080/10584609.2018.1517843 


\section{Artikkelit: Social Media + Society, $\mathbf{n}=\mathbf{3 3}$}

Alaimo, K. (2015). How the Facebook Arabic Page "We Are All Khaled Said" Helped Promote the Egyptian Revolution. Social Media + Society, 1(2), 2056305115604854. https://doi. org/10.1177/2056305115604854

Bastos, M., \& Farkas, J. (2019). “Donald Trump Is My President!”: The Internet Research Agency Propaganda Machine. Social Media + Society, 5(3), 2056305119865466. https://doi. org $/ 10.1177 / 2056305119865466$

Ceia, V. (2020). Digital Ecosystems of Ideology: Linked Media as Rhetoric in Spanish Political Tweets. Social Media + Society, 6(2), 2056305120926630. https://doi.org/ $10.1177 / 2056305120926630$

Coe, K., \& Griffin, R. A. (2020). Marginalized Identity Invocation Online: The Case of President Donald Trump on Twitter. Social Media + Society, 6(1), 2056305120913979. https://doi. org/10.1177/2056305120913979

Dawson, V. R. (2018). Fans, Friends, Advocates, Ambassadors, and Haters: Social Media Communities and the Communicative Constitution of Organizational Identity. Social Media + Society, 4(1), 2056305117746356. https://doi .org/10.1177/2056305117746356

Ernst, N., Blassnig, S., Engesser, S., Büchel, F., \& Esser, F. (2019). Populists Prefer Social Media Over Talk Shows: An Analysis of Populist Messages and Stylistic Elements Across Six Countries. Social Media + Society, 5(1), 2056305118823358. https://doi.org/10.1177/ 2056305118823358

Evans, H. K., Smith, S., Gonzales, A., \& Strouse, K. (2017). Mudslinging on Twitter During the 2014 Election. Social Media + Society, 3(2), 2056305117704408. https://doi. org/10.1177/2056305117704408

Gantt Shafer, J. (2017). Donald Trump's "Political Incorrectness": Neoliberalism as Frontstage Racism on Social Media. Social Media + Society, 3(3), 205630511773322. https://doi. org $/ 10.1177 / 2056305117733226$

Gerbaudo, P., Marogna, F., \& Alzetta, C. (2019). When "Positive Posting" Attracts Voters: User Engagement and Emotions in the 2017 UK Election Campaign on Facebook. Social Media + Society, 5(4), 205630511988169. https://doi.org/10.1177/2056305119881695

Groshek, J., \& Cutino, C. (2016). Meaner on Mobile: Incivility and Impoliteness in Communicating Contentious Politics on Sociotechnical Networks. Social Media + Society, 2(4), 205630511667713. https://doi.org/10.1177/2056305116677137

Guerrero-Solé, F. (2018). Interactive Behavior in Political Discussions on Twitter: Politicians, Media, and Citizens' Patterns of Interaction in the 2015 and 2016 Electoral Campaigns in Spain. Social Media + Society, 4(4), 205630511880877. https://doi.org/10.1177/ 2056305118808776

Hedman, U. (2016). When Journalists Tweet: Disclosure, Participatory, and Personal Transparency. Social Media + Society, 2(1), 205630511562452. https://doi.org/10.1177/ 2056305115624528

Humprecht, E., Hellmueller, L., \& Lischka, J. A. (2020). Hostile Emotions in News Comments: A Cross-National Analysis of Facebook Discussions. Social Media + Society, 6(1), 205630512091248. https://doi.org/10.1177/2056305120912481 
Kim, H., Jang, S. M., Kim, S.-H., \& Wan, A. (2018). Evaluating Sampling Methods for Content Analysis of Twitter Data. Social Media + Society, 4(2), 205630511877283. https://doi. org/10.1177/2056305118772836

Kligler-Vilenchik, N., Baden, C., \& Yarchi, M. (2020). Interpretative Polarization across Platforms: How Political Disagreement Develops Over Time on Facebook, Twitter, and WhatsApp. Social Media + Society, 6(3), 205630512094439. https://doi.org/10.1177/2056305120944393

Maly, I. (2019). New Right Metapolitics and the Algorithmic Activism of Schild \& Vrienden. Social Media + Society, 5(2), 205630511985670. https://doi.org/10.1177/2056305119856700

Masroor, F., Khan, Q. N., Aib, I., \& Ali, Z. (2019). Polarization and Ideological Weaving in Twitter Discourse of Politicians. Social Media + Society, 5(4), 205630511989122. https://doi. org/10.1177/2056305119891220

McGregor, S. C., \& Mourão, R. R. (2016). Talking Politics on Twitter: Gender, Elections, and Social Networks. Social Media + Society, 2(3), 205630511666421. https://doi.org/ $10.1177 / 2056305116664218$

Nelimarkka, M., Laaksonen, S.-M., Tuokko, M., \& Valkonen, T. (2020). Platformed Interactions: How Social Media Platforms Relate to Candidate-Constituent Interaction During Finnish 2015 Election Campaigning. Social Media + Society, 6(2), 205630512090385. https://doi. org/10.1177/2056305120903856

Nuernbergk, C., \& Conrad, J. (2016). Conversations and Campaign Dynamics in a Hybrid Media Environment: Use of Twitter by Members of the German Bundestag. Social Media + Society, 2(1), 205630511662888. https://doi.org/10.1177/2056305116628888

Pain, P., \& Masullo Chen, G. (2019). The President Is in: Public Opinion and the Presidential Use of Twitter. Social Media + Society, 5(2), 205630511985514. https://doi. org/10.1177/2056305119855143

Rauchfleisch, A., Artho, X., Metag, J., Post, S., \& Schäfer, M. S. (2017). How journalists verify user-generated content during terrorist crises. Analyzing Twitter communication during the Brussels attacks. Social Media + Society, 3(3), 205630511771788. https://doi. org/10.1177/2056305117717888

Recuero, R., Zago, G., \& Soares, F. (2019). Using Social Network Analysis and Social Capital to Identify User Roles on Polarized Political Conversations on Twitter. Social Media + Society, 5(2), 205630511984874. https://doi.org/10.1177/2056305119848745

Ron, Y., Suleiman, C., \& Maoz, I. (2020). Women for Peace: Promoting Dialogue and Peace through Facebook? Social Media + Society, 6(4), 205630512098446. https://doi. org/10.1177/2056305120984461

Ross, A. S., \& Rivers, D. J. (2018). Discursive Deflection: Accusation of "Fake News" and the Spread of Mis- and Disinformation in the Tweets of President Trump. Social Media + Society, 4(2), 205630511877601. https://doi.org/10.1177/2056305118776010

Rossini, P., Hemsley, J., Tanupabrungsun, S., Zhang, F., \& Stromer-Galley, J. (2018). Social Media, Opinion Polls, and the Use of Persuasive Messages During the 2016 US Election Primaries. Social Media + Society, 4(3), 205630511878477. https://doi.org/10.1177/2056305118784774 Ruiz-Soler, J., Curini, L., \& Ceron, A. (2019). Commenting on Political Topics Through Twitter: Is European Politics European? Social Media + Society, 5(4), 205630511989088. https:// doi.org/10.1177/2056305119890882 
Sahly, A., Shao, C., \& Kwon, K. H. (2019). Social Media for Political Campaigns: An Examination of Trump's and Clinton's Frame Building and Its Effect on Audience Engagement. Social Media + Society, 5(2), 205630511985514. https://doi.org/10.1177/2056305119855141

Savolainen, L., Trilling, D., \& Liotsiou, D. (2020). Delighting and Detesting Engagement: Emotional Politics of Junk News. Social Media + Society, 6(4), 205630512097203. https://doi. org/10.1177/2056305120972037

Schreiner, T. (2018). Information, Opinion, or Rumor? The Role of Twitter During the PostElectoral Crisis in Côte d'Ivoire. Social Media + Society, 4(1), 205630511876573. https:// doi.org/10.1177/2056305118765736

Smyrnaios, N., \& Ratinaud, P. (2017). The Charlie Hebdo Attacks on Twitter: A Comparative Analysis of a Political Controversy in English and French. Social Media + Society, 3(1), 205630511769364. https://doi.org/10.1177/2056305117693647

Van Duyn, E. (2020). Mainstream Marginalization: Secret Political Organizing Through Social Media. Social Media + Society, 6(4), 2056305120981044. https://doi.org/ $10.1177 / 2056305120981044$

Yantseva, V. (2020). Migration Discourse in Sweden: Frames and Sentiments in Mainstream and Social Media. Social Media + Society, 6(4), 205630512098105. https://doi. org/10.1177/2056305120981059 